\title{
Type 1 IFN-alpha Receptor Expression in Peripheral Blood Lymphocytes Independently Predicts Sustained Virological Response in Chronic Hepatitis C Genotype 1b with High Viral Load
}

\section{Kaori Kanayama, Koji Ishii*, Mie Shinohara, Michio Kogame, and Yasukiyo Sumino}

Division of Gastroenterology and Hepatology, Department of Internal Medicine, Toho University School of Medicine, Toho University, 6-11-1, Omorinishi, Otaku, Tokyo 143-8541, Japan

\begin{abstract}
Background: We have been investigating serial changes in Type I Interferon (IFN) receptor alpha-2 (IFNAR-2) expression in peripheral blood leukocyte subsets in Chronic Hepatitis $\mathrm{C}(\mathrm{CHC})$ patients during IFN-based therapy. The aim of this study was to clarify whether changes in IFNAR-2 expression by peripheral blood leukocyte subsets are predictive factors for Sustained Virological Response (SVR).
\end{abstract}

Methods: One hundred and thirty-six patients with $\mathrm{CHC}$ and receiving Pegylated (PEG)-IFN alpha-2a or -2b in combination with ribavirin (RBV) for a median 48 (16-96) weeks were studied. A negative result for serum HCV-RNA on RT-PCR at week 24 after the End Of Therapy (EOT) was defined as SVR. IFNAR-2 expression by peripheral blood leukocyte subsets was quantified using flow cytometry by measuring the mean fluorescence intensity before and up to 28 days after therapy initiation. Of the 136 patients, 124 consented to genetic investigation for interleukin (IL)-28B genetic variants at rs8099917. We then used logistic regression analysis to retrospectively investigate the influence of serum viral load, as measured before the start of therapy, and age, sex, body weight, body mass index, IFN regimen, IFN dose/kg, RBV dose/kg and history of prior IFN-based therapy on SVR.

Results: Overall SVR rate was 53\% (77/146). Of the 97 patients with IL-28 genotype TT, $67(69 \%)$ showed SVR. In contrast, of the 27 patients with IL-28 genotype TG, 5 (19\%) showed SVR. IL-28B genotype at rs8099917 and patient age were factors having an independent influence on SVR on multivariate regression analysis. When we added serial changes in IFNAR-2 expression by leukocyte subsets before and up to 28 days after EOT to the logistic regression model, IFNAR-2 expression by lymphocytes at day 28 was identified as an independent additive factor.

Conclusion: This study provided the first evidence that IFNAR-2 expression by peripheral blood lymphocytes is an additive but independent factor predicting SVR to PEG-IFN and RBV in patients with CHC genotype $1 \mathrm{~b}$ and high viral load.

Keywords: Chronic hepatitis C; Interleukin-28B; Type 1 interferon receptor 2; Peripheral blood lymphocyte; HCV genotype $1 \mathrm{~b}$

\section{Introduction}

Several Single Nucleotide Polymorphisms (SNPs) in the Interleukin (IL)-28B gene are associated with Sustained Virological Response (SVR) to pegylated (PEG)-interferon (IFN) and ribavirin (RBV) in patients having Chronic Hepatitis $\mathrm{C}(\mathrm{CHC})$ genotype $1 \mathrm{~b}$ and high viral load [1-3]. The mapped region (19q13) encodes 3 cytokine genes (IL28A, IL-28B and IL-29) that belong to the IFN-lambda (also known as type 3 IFN) family induced by viral infection and has antiviral activity [4]. IFN-lambdas, similar to IFN-alphas, are thought to stimulate the IFN signal pathway, which includes phosphorylation of the kinases JAK1 and Tyk2, activation of transcription factor complex containing STAT1, STAT2 and IFN regulatory factor 9, and up-regulation of a similar set of ISGs, after binding to heterodimeric receptor consisting of IL10R-beta and IL28R-alpha (IFN-lambdaR1) [5,6]. Finally, antiviral substances such as 2'-5'oligoadenylate synthetase, PKR, MxA and IL-8, are induced $[7,8]$.

In addition to IFN-lambda, intracellular signaling is initiated after binding of IFN-alpha to type I IFN-alpha receptor1 (IFNAR-1) and IFNAR-2 on the plasma membrane of target cells [9]. We have been investigating serial changes in IFNAR-2 expression in peripheral blood leukocyte subsets in CHC patients during IFN-based therapy $[10,11]$.

The aim of this study was to clarify whether changes in IFNAR-2 expression by peripheral blood leukocyte subsets are predictive of SVR.

\section{Patients and Methods}

From patients with CHC who received PEG-IFN alpha-2a or $-2 b$ in combination with RBV, treated at our hospital between January 2005 and June 2010, and in whom IFNAR-2 expression by peripheral blood leukocyte subsets were measured, 136 consecutive patients were selected.

All patients were positive for anti-HCV antibody on thirdgeneration Enzyme-Linked Immunosorbent Assay (ELISA) and for serum HCV-RNA quantified on COBAS TaqMan HCV test (Chugai Pharmaceutical Co., Ltd., Tokyo, Japan; lower detection limit, 1.2 log

*Corresponding author: Koji Ishii, Division of Gastroenterology and Hepatology, Department of Internal Medicine, Toho University School of Medicine, Toho University, 6-11-1 Omorinishi, Ota-ku, Tokyo 143-8541, Japan, Tel: +81-3-37624151; Fax: +81-3-3763-8542; E-mail: iskoji377@med.toho-u.ac.jp

Received September 28, 2012; Accepted October 30, 2012; Published November 01, 2012

Citation: Kanayama K, Ishii K, Shinohara M, Kogame M, Sumino Y (2012) Type 1 IFN-alpha Receptor Expression in Peripheral Blood Lymphocytes Independently Predicts Sustained Virological Response in Chronic Hepatitis C Genotype 1b with High Viral Load. J Blood Lymph 2:109. doi:10.4172/2165-7831.1000109

Copyright: (C) 2012 Kanayama K, et al. This is an open-access article distributed under the terms of the Creative Commons Attribution License, which permits unrestricted use, distribution, and reproduction in any medium, provided the original author and source are credited. 
Citation: Kanayama K, Ishii K, Shinohara M, Kogame M, Sumino Y (2012) Type 1 IFN-alpha Receptor Expression in Peripheral Blood Lymphocytes Independently Predicts Sustained Virological Response in Chronic Hepatitis C Genotype 1b with High Viral Load. J Blood Lymph 2:109. doi:10.4172/2165-7831.1000109

Page 2 of 5

copies/ml; upper limit, 7.8 log copies/ml). Serum levels of HCV-RNA in the subjects ranged (10th - 90th percentiles) from 5.1 to 6.9 (median: 6.4) $\log$ copies/ml.

Enrolment criteria for patients with CHC (79 men and 57 women) included age ranging $\left(10^{\text {th }}-90^{\text {th }}\right.$ percentiles $)$ from 41 to 67 years (median: 57 years). All patients were infected with HCV genotype $1 b$, and received a course of therapy with PEG-IFN alpha- $2 \mathrm{a}$ or $-2 \mathrm{~b}$ in combination with RBV (Table 1). Patients who were known to be homosexual or intravenous drug users, those positive for hepatitis B surface antigen or antinuclear antibody, and those with metabolic liver dysfunction or renal dysfunction were excluded.

Of the 136 patients, 92 patients had undergone percutaneous liver biopsy before combination therapy under ultrasonographic control, and the tissue specimens thus obtained were graded according to the Histology Activity Index (HAI) of Knodell et al. [12], after which the specimens were divided into three groups according to Desmet [13]: Grade 1 for HAI scores of 1-3; Grade 2 for HAI scores of 4-8; and Grade 3 for HAI scores of 9 or more. Specimens were also divided into four groups from stage 1 to stage 4 based on Desmet fibrosis scores [13].

\section{IFN regimens}

After providing informed consent, 44 patients received PEG-IFN alpha-2a (Pegasys ${ }^{\star}$, Chugai Pharmaceutical Co., Ltd., Japan) for a median of $48\left(10^{\text {th }}-90^{\text {th }}\right.$ percentiles: $\left.48-72\right)$ weeks at a weekly dose of $180 \mu \mathrm{g}$. Ninety-two patients received PEG-IFN alpha-2b (PegIntron", Schering Plough Co., Ltd., Japan $)$ for a median of $48\left(10^{\text {th }}-90^{\text {th }}\right.$ percentiles: 48 - 72) weeks at weekly doses adjusted for body weight according to the manufacturer's instructions $(45 \mathrm{~kg}$ or less $=60 \mu \mathrm{g} /$ dose, 46 to $60 \mathrm{~kg}=80 \mu \mathrm{g} /$ dose, 61 to $75 \mathrm{~kg}=100 \mu \mathrm{g} /$ dose, 76 to $90 \mathrm{~kg}=$ $120 \mu \mathrm{g} /$ dose, and 91 or more $=150 \mu \mathrm{g} /$ dose) .

RBV (Rebetol ${ }^{\circledR}$, Schering Plough Co., Ltd., or Copegus ${ }^{\oplus}$, Chugai Pharmaceutical Co., Ltd.) was given orally at daily doses adjusted for body weight according to the manufacturer's instructions ( $60 \mathrm{~kg}$ or less $=600 \mathrm{mg} /$ day, 61 to $80 \mathrm{~kg}=800 \mathrm{mg} /$ day, and $81 \mathrm{~kg}$ or more $=1,000$ $\mathrm{mg} /$ day) for a median of 48 (ranging $10^{\text {th }}-90^{\text {th }}$ percentiles: $48-72$ ) weeks.

\begin{tabular}{|l|l|}
\hline No of patients $(\mathbf{n})$ & 136 \\
\hline Age $(\mathbf{y})$ & $57(41-67)$ \\
\hline Sex (M/F) & $79 / 57$ \\
\hline IL28 (TT/TG/GG/ None) & $97 / 27 / 0 / 12$ \\
\hline Substitution & \\
\hline aa70 (Wild/Mutant/None) & $55 / 36 / 45$ \\
\hline aa91 (Wild/Mutant/None) & $67 / 23 / 46$ \\
\hline ISDR (0-1/>2/None) & $46 / 47 / 43$ \\
\hline Serum & \\
\hline HCV-RNA (Log copies/ml) & $6.5(5.5-6.5)$ \\
\hline AST (IU/I) & $51(24-131)$ \\
\hline AST (IU/I) & $58(24-161)$ \\
\hline Peripheral Blood & \\
\hline WBC $\left(10^{3} / \mathrm{mm}^{3}\right)$ & $4.9(3.1-7.5)$ \\
\hline RBC (10//mm $\left.{ }^{3}\right)$ & $445(390-499)$ \\
\hline PLT (104/mm $\left.{ }^{3}\right)$ & $15.5(9.1-24.1)$ \\
\hline Pathological findings & \\
\hline Activity (1/2/3/None) & $43 / 47 / 2 / 44$ \\
\hline Fibrosis (1/2/3/4/None) & $32 / 32 / 15 / 13 / 44$ \\
\hline
\end{tabular}

Note: Data are given as median values and ranges show $10^{\text {th }}-90^{\text {th }}$ percentiles.

Table 1: Patient background data.
Some patients needed slight adjustment of the RBV doses, because of a decrease in hemoglobin during therapy.

\section{Viral kinetic study}

Serum HCV-RNA was measured using the COBAS TaqMan HCV test before the start of therapy and every 4 weeks thereafter until the end of therapy, as well as at 24 weeks after the end of therapy. Sustained viral response (SVR) was defined as being negative for serum HCVRNA by COBAS TaqMan HCV test at 24 weeks after the end of therapy. Other patterns were non-SVR, including non-responder (serum HCVRNA levels detectable after completed treatment period) and relapsed responder patients (undetectable serum HCV-RNA during therapy, but detectable after discontinuation).

\section{Genetic variations in IL28B gene}

Of 136 CHC patients, 124 consented to genetic testing, and SNPs in IL-28B gene were thus analyzed (Table 2). The region on chromosome 19 associated with HCV treatment response contains several SNPs in linkage disequilibrium around the IL28B gene. Whole blood samples for a genome-wide association survey were genotyped using the Illumina HumanHap 610-Quad Genotyping BredCrip. Genotyping for replication and fine mapping was performed using Invador assay, TaqMan assay, or direct sequencing, as described previously [14,15]. In this study, genetic variations near the IL-28B gene (rs 8099917), reported as pretreatment predictors of treatment efficacy and clinical outcome in Japanese, were investigated [1]. As IL-28B genotype GG was not detected in $\mathrm{CHC}$ patients, patients were divided into 2 groups; those with IL-28B genotype TT ( $\mathrm{n}=97)$ and those with IL-28B genotype TG $(\mathrm{n}=27)$.

\section{Assays}

Blood samples were collected from all patients before and at 3 , 7, 14 and 28 days after the start of IFN therapy. IFNAR-2 expression by peripheral leukocyte subsets- lymphocytes (Ly), monocytes (Mo) and granulocytes $(\mathrm{Gr})$ - were then determined by flow cytometry to measure the Mean Fluorescence Intensity (MFI) after staining with anti-IFNAR-2 antibody, as reported previously [16].

\begin{tabular}{|c|c|c|c|}
\hline & TT & TG & \\
\hline No of patients $(n)$ & 97 & 27 & \\
\hline Age (y) & $57(41-67)$ & $53(41-65)$ & NS \\
\hline $\operatorname{Sex}(M / F)$ & $54 / 43$ & $15 / 12$ & NS \\
\hline \multicolumn{4}{|l|}{ Substitution } \\
\hline aa70 (Wild/Mutant/None) & $48 / 21 / 28$ & $6 / 13 / 8$ & $<0.01$ \\
\hline aa91 (Wild/Mutant/None) & $52 / 17 / 28$ & $12 / 7 / 8$ & NS \\
\hline ISDR (0-1/>2/None) & $30 / 40 / 27$ & $13 / 6 / 8$ & NS \\
\hline \multicolumn{4}{|l|}{ Serum } \\
\hline HCV-RNA (Log copies/ml) & $6.5(5.0-6.9)$ & $6.5(5.8-6.9)$ & NS \\
\hline AST (IU/I) & $51(24-130)$ & $52(27-124)$ & NS \\
\hline AST (IU/I) & $64(24-158)$ & $58(24-154)$ & NS \\
\hline $\mathrm{Fe}$ & $122(65-220)$ & $136(87-250)$ & NS \\
\hline \multicolumn{4}{|l|}{ Peripheral Blood } \\
\hline WBC $\left(10^{3} / \mathrm{mm}^{3}\right)$ & $4.9(3.1-7.4)$ & $5.1(3.6-7.5)$ & NS \\
\hline $\mathrm{RBC}\left(10^{4} / \mathrm{mm}^{3}\right)$ & $443(392-500)$ & $450(391-496)$ & NS \\
\hline $\operatorname{PLT}\left(10^{4} / \mathrm{mm}^{3}\right)$ & $15.6(9.2-24.1)$ & $15.0(11.8-24.1)$ & NS \\
\hline \multicolumn{4}{|l|}{ Pathological findings } \\
\hline Activity (1/2/3/None) & $29 / 33 / 2 / 33$ & $12 / 8 / 0 / 7$ & NS \\
\hline Fibrosis (1/2/3/4/None) & 22/25/9/10/31 & $7 / 8 / 3 / 2 / 7$ & NS \\
\hline
\end{tabular}

Note: Data are given as median values and ranges show $10^{\text {th }}-90^{\text {th }}$ percentiles

Table 2: Background of patients with IL28 patients. 
Citation: Kanayama K, Ishii K, Shinohara M, Kogame M, Sumino Y (2012) Type 1 IFN-alpha Receptor Expression in Peripheral Blood Lymphocytes Independently Predicts Sustained Virological Response in Chronic Hepatitis C Genotype 1b with High Viral Load. J Blood Lymph 2:109. doi:10.4172/2165-7831.1000109

Page 3 of 5

\section{Statistical analysis}

Results are presented as medians and $10^{\text {th }}-90^{\text {th }}$ percentiles. Chi squared test was used to compare characteristics between the groups.

We used logistic regression analysis to retrospectively investigate the influence of serum viral load, as measured before the start of therapy, and age, sex, body weight, body mass index, IFN regimen, IFN dose $/ \mathrm{kg}$, RBV dose/kg and history of prior IFN-based therapy on SVR.

\section{Results}

\section{SVR rates}

Overall SVR rate was $57 \%(77 / 136)$. Of the 97 patients with IL28 genotype TT, 66 patients (68\%) showed SVR. In contrast, of the 27 patients with IL-28 genotype TG, 5 patients (19\%) showed SVR (Figure $1)$.

\section{Logistic regression analysis}

IL-28B genotype at rs8099917 and patient age were factors having an independent influence on SVR on multivariate regression analysis (Table 3).

When we added serial changes in IFNAR-2 expression by Ly, Mo and $\mathrm{Gr}$ before and up to 28 days after the start of therapy to the logistic regression model, IFNAR-2 expression by Ly at day 28 was identified as an independent additive factor (Table 4). Serial expression by peripheral blood Ly before and up to 28 days after the start of therapy
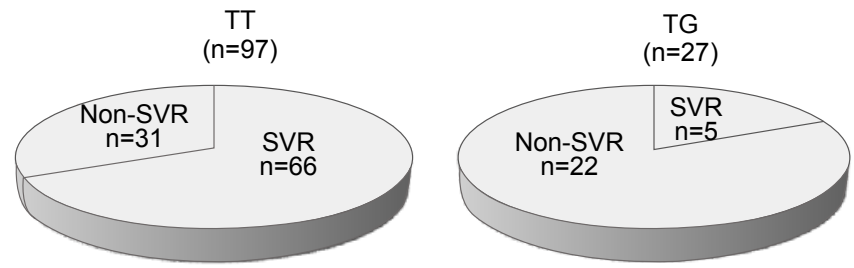

Figure 1: Sustained virological response (SVR) by interleukin (IL)-28B genotype. Of the 97 patients with interleukin (IL)-28B genotype TT, $66(68 \%)$ showed SVR. In contrast, of the 27 patients with IL-28B genotype TG, 5 (19\%) showed SVR.

\begin{tabular}{|c|c|c|c|}
\hline & SVR & Non SVR & \\
\hline & $(n=77)$ & $(n=59)$ & $p$ value \\
\hline Age (y) & $54(41-66)$ & $59(45-69)$ & $P<0.01$ \\
\hline $\operatorname{Sex}(M / F)$ & $52 / 25$ & $27 / 32$ & $P=0.01$ \\
\hline \multicolumn{4}{|l|}{ Peripheral Blood } \\
\hline $\begin{array}{l}\text { Pretreatment level } \\
\text { of WBC }\left(10^{3} / \mathrm{mm}^{3}\right)\end{array}$ & $5.0(3.3-7.6)$ & $4.9(3.0-7.4)$ & NS \\
\hline \multicolumn{4}{|l|}{ Serum } \\
\hline $\begin{array}{l}\text { HCV-RNA (Log } \\
\text { copies/ml) }\end{array}$ & $6.5(5.0-6.9)$ & $6.5(5.8-6.9)$ & NS \\
\hline AST (IU/I) & $51(25-130)$ & $51(23-131)$ & NS \\
\hline AST (IU/I) & $64(25-165)$ & $55(23-143)$ & NS \\
\hline $\mathrm{Fe}$ & $134(73-237)$ & $119(76-224)$ & NS \\
\hline \multicolumn{4}{|l|}{ At D28 } \\
\hline $\begin{array}{l}\text { Expression of } \\
\text { IFNAR2 by Ly }\end{array}$ & $0.5(0.4-0.7)$ & $0.6(0.4-0.7)$ & NS \\
\hline
\end{tabular}

Ly= lymphocytes

Table 3: Logistic regression model. in the SVR patients and the non-SVR patients were determined (Figure 2 ), and in the SVR patients, was found to steadily decrease.

\section{Discussion}

In this study, logistic regression analysis showed that strong predictors for SVR to PEG-IFN and RBV in patients having CHC genotype $1 \mathrm{~b}$ and high viral load were the IL-28B genotype at rs 8099917 and patient age. Until IL-28B SNPs were discovered as strong predictors for SVR by IFN-based therapy, patient age had been reported as one of the most predictive factors for SVR to IFN therapy in CHC patients [17]. Even after IL-28B SNPs were discovered, patient age remained a strong predictor in addition to IL-28B SNPs [18].

However, IL-28B SNPs were the strongest predictive factor for therapy with PEG-IFN and RBV in CHC patients infected genotype 2 [19], 3 [20] and 4 [21], in addition to genotype 1 [1-3]. Recent reports have suggested that non-responder genotypes (TG or GG) at rs8099917 are associated with higher expression of Interferon Stimulating Genes (ISGs) in the liver prior to antiviral treatment and ultimately treatment failure [22]. Induction of ISGs is initiated after the binding of IFNalpha to INFAR-2 and of IFN-lambda to a receptor, IFN-lambdaR1, on the plasma membrane of target cells $[23,24]$. On the other hand, some clinical studies have found that IFNAR expression is correlated with response to IFN-alpha therapy in CHC. Taniguchi et al. [22] reported that high intrahepatic mRNA levels of IFNAR-1 and ratio of IFNA-1 to IFNAR-2 were significantly higher in patients having SVR to IFNalpha therapy. Fujiwara et al. found that the IFNAR-2 expression levels in the liver are predictive of response to IFN-alpha treatment in $\mathrm{CHC}$ patients. IFNARs are expressed on the cell membrane of

\begin{tabular}{|l|c|c|c|c|}
\hline & Estimate & Standard error & $\mathbf{X}^{\mathbf{2}}$ & P value \\
\hline Intercept & 6.59738182 & 2.0084967 & 10.79 & $0.0010^{*}$ \\
\hline Rs8099917 (TT) & 1.7883095 & 0.3963952 & 20.35 & $<0.001^{*}$ \\
\hline Age & -0.1176582 & 0.0356905 & 10.87 & $0.0010^{*}$ \\
\hline
\end{tabular}

When we added serial changes in IFNAR-2 expression by lymphocytes, monocytes and granulocytes before therapy up to 28 days after EOT to the logistic regression model, IFNAR-2 expression by lymphocytes at day 28 was identified as an independent additive factor

\begin{tabular}{l|l|l|l|l|}
\hline $\begin{array}{l}\text { Change in } \\
\text { IFNAR-2 } \\
\text { expression by } \\
\text { lymphocytes at } \\
\text { day } 28\end{array}$ & 6.02008034 & 2.6303472 & 5.24 & $0.0221^{*}$ \\
\hline
\end{tabular}

Table 4: Logistic regression model.

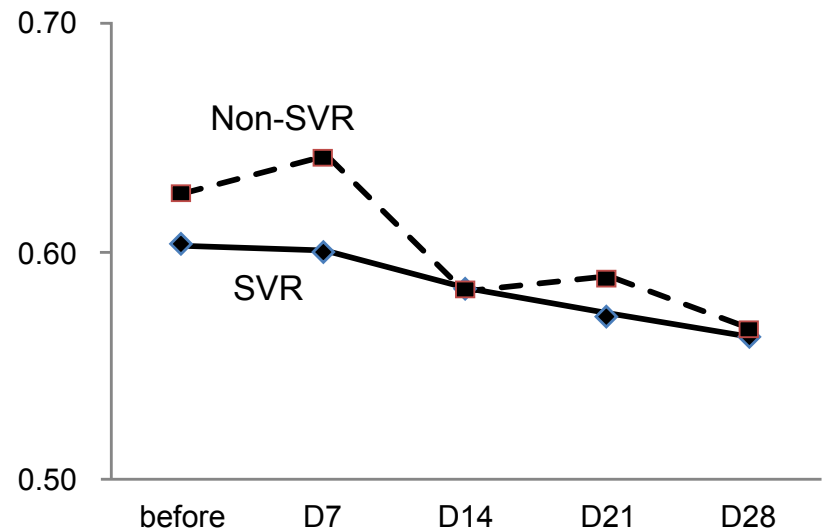

Figure 2: Serial expression by peripheral blood Lymphocyte (Ly) before therapy and up to 28 days after the start of therapy in Sustained Virological Response (SVR) patients and the non-SVR patients. 
Citation: Kanayama K, Ishii K, Shinohara M, Kogame M, Sumino Y (2012) Type 1 IFN-alpha Receptor Expression in Peripheral Blood Lymphocytes Independently Predicts Sustained Virological Response in Chronic Hepatitis C Genotype 1b with High Viral Load. J Blood Lymph 2:109. doi:10.4172/2165-7831.1000109

Page 4 of 5

peripheral blood mononuclear cells, as well as hepatocytes [23]. It is not easy to observe serial changes in IFNAR-2 expression in the liver after combination therapy with PEG-IFN and RBV in CHC patients. As hepatic expression of IFNAR-2 and its expression by peripheral blood mononuclear cells are reported to be correlated [24], it may be valuable to observe serial changes in receptor expression on peripheral blood leukocyte subsets. It is also thought that assessing expression of the functional IFN receptor is useful, as IFNAR proteins located on the cell membrane are functional, but intracellular receptor proteins are not. Flow cytometry makes it possible to determine the amount of a particular receptor protein expressed on the surface of peripheral blood leukocyte subsets in CHC patients.

This study showed that serial changes in IFNAR-2 expression by peripheral blood Ly up to 28 days after initiating therapy are an independent factor predicting SVR to PEG-IFN and RBV in patients with $\mathrm{CHC}$ genotype $1 \mathrm{~b}$ and high viral load, in addition to IL-28B genotype and patient age. Therapy with PEG-IFN and RBV may be more effective when IFNAR-2 expression by peripheral blood Ly fell smoothly up to 28 days after initiating therapy either in patients having responder genotype or in patients having non-responder genotype [25]. The steady decrease in IFNAR-2 expression by peripheral blood Ly for up to 28 days after initiating therapy in the SVR patients appears to be ligand-dependent receptor down-regulation, which is a wellknown phenomenon for ligands and receptors, such as Epidermal Growth Factor (EGF) and EGF-receptor. On binding to its receptor, EGF initiates a cascade of events leading to cell proliferation or differentiation. In addition, the EGF receptor itself is down-regulated to attenuate mitogenic signaling [26]. On binding to IFNARs, IFN-alpha initiates a cascade of events leading production of antiviral substances. HCV is able to infect peripheral blood mononuclear cells, lymphocytes and monocytes, as well as hepatocytes.

Datta et al. [27] reported that HCV infection directly modulates IFNAR expression. IFNAR-2 expression by peripheral blood Ly may decreases when HCV infecting peripheral blood Ly is diminished or cleared. The mechanism of down-regulation of IFNAR-2 expression in the HCV replicating cells may be due to the phosphorylationdependent ubiquitination and degradation of IFNAR-2.

To date, we have reported that IFNAR-2 expression by peripheral blood Mo during early phase of IFN-based therapy was related with early virological response $[10,11]$. However, in this multivariate analysis, the amount of change in IFNAR-2 expression by peripheral blood Ly was selected as a predictor for SVR, but not IFNAR-2 expression by peripheral blood Mo. Mo is known to be activated in inflamed liver and to secrete antiviral cytokines, and is associated with innate immunity. On the other hand, Ly including $\mathrm{B}$ cells and T cells is associated with adaptive immunity and results in removal of virus from infected cells. The distribution of viral variants among mononuclear cells is different, and changes in IFNAR-2 expression by peripheral Ly were more indicative of HCV eradication from infected cells than those in IFNAR-2 by peripheral blood Mo in this study.

In conclusion, this study provided the first evidence that, in addition to IL-28B genotype at rs8099917 and patient age, IFNAR-2 expression by peripheral blood Ly is an additive, but independent, factor predicting SVR to PEG-IFN and RBV in patients with CHC genotype $1 \mathrm{~b}$ and high viral load.

\section{References}

1. Tanaka Y, Nishida N, Sawai H, Sugiyama M, Kurosaki M, et al. (2009) Genome-
Wide association of IL-28B with response to pegylated interferon- alpha and ribavirin for chronic hepatitis C. Nat Genet 41: 1105-1109.

2. Ge D, Fellay J, Thompson AJ, Simon JS, Shianna KV, et al. (2009) Genetic variation in IL-28B predicts hepatitis C treatment-induced viral clearance. Nature 461: 399-401.

3. Suppiah V, Moldovan M, Ahlenstiel G, Berg T, Weltman M, et al. (2009) IL-28B is associated with response to chronic hepatitis $C$ interferon- $\alpha$ and ribavirin therapy. Nat Genet 41: 1100-1104.

4. Ank N, West H, Bartholdy C, Erikson K, Thomsen AR, et al. (2006) Lambda interferon (IFN-lambda), a type III IFN, is induced by viruses and IFNs and display potent antiviral activity against select virus infections in vivo. J Virol 80 4501-4509.

5. Kotenko SV, Gallagher G, Baurin VV, Lewis-Antes A, Shen M, et al. (2003) IFN-lambda mediates antiviral protection through a distinct class II cytokine receptor complex. Nat Immunol 4: 69-77.

6. Li M, Liu X, Zhou Y, Su SB (2009) Interferon-lambda: the modulators of antivirus, antitumor, and immune response. J Leukoc Biol 86: 23-32.

7. Chen X, Bhandari R, Vinkemeier U, Van Den Akker F, Darnell JE, et al. (2003) $A$ reinterpretation of the dimerization interface of the $\mathrm{N}$-terminal domains of STATs. Protein Sci 12: 361- 365.

8. Kisseleva T, Bhattacharya S, Braunstein J, Schindler CW (2002) Signaling through the JAK/STAT pathway, recent advances and future challenges. Gene 285: $1-24$.

9. Afdhal NH, McHutchison JG, Zeuzem S, Mangia A, Pawlotsky JM, et al. (2011) Hepatitis C pharmacogenetics: state of the Art in 2010. Hepatology 53: 336 345 .

10. Ishii K, Shinohara M, Sawa M, Kogame M, Higami K, et al. (2010) Interferon alpha receptor 2 expression by peripheral blood monocytes in patients with a high viral load of hepatitis $C$ virus genotype 1 showing substitution of amino acid 70 in the core region. Intervirology 53: 105-110.

11. Ishii K, Shinohara M, Kanayama K, Kogame M, Shiratori M, et al. (2012) Interleukin-28B genetic variants and peripheral blood interferon receptor 2 . J Blood Lymph 2: 1-5.

12. Knodell RG, Ishak KG, Black WC, Chen TS, Craig R, et al. (1981) Formulation and application of a numerical scoring system for assessing histological activity in asymptomatic chronic hepatitis. Hepatology 1: 431-435.

13. Desmet VJ, Gerber M, Hoofnagle JH, Manns M, Scheuer PJ (1994) Classification of chronic hepatitis: diagnosis, grading and staging. Hepatology 19: $1513-1520$

14. Ohnishi Y, Tanaka T, Ozaki K, Yamada R, Suzuki H, et al. (2001) A highthroughput SNP typing system for genome-wide association studies. J Hum Genet 46: 471-477.

15. Suzuki A, Yamada R, Chang X, Tokuhiro S, Sawada T, et al. (2003) Functiona haplotypes of PADI4, encoding citrullinating enzyme peptidylarginine deiminase 4 , are associated with rheumatoid arthritis. Nat Genet 34: 395-402.

16. Tochizawa S, Akamatsu S, Sugiyama Y, Muraguchi M, Ohmoto Y, et al. (2004) A flow cytometric method for determination of the interferon receptor IFNAR-2 subsets in peripheral blood leukocyte subsets. J Pharmacol Toxicol Methods 50: $59-66$

17. Kogure T, Ueno Y, Fukushima K, Nagasaki F, Kondo Y, et al. (2008) Pegylated interferon plus ribavirin for genotype $1 \mathrm{~b}$ chronic hepatitis $\mathrm{C}$ in Japan. World $\mathrm{J}$ Gastroenterol 14: 7225-7230.

18. Miyaaki H, Ichikawa T, Yatsuhashi H, Taura N, Miuma S, et al. (2011) Suppressor of cytokine signal 3 and IL28 genetic variation predict the viral response to peginterfeon and ribavirin. Hepatol Res 41: 1216-1222.

19. Yu ML, Huang CF, Huang JF, Chang NC, Yang JF, et al. (2011) Role of interleukin-28B polymorphism in the treatment of hepatitis $\mathrm{C}$ virus genotype 2 infection in Asian patients. Hepatology 53: 7-13.

20. Moghaddam A, Melum E, Reinton N, Ring-Larsen H, Verbaan H, et al. (2011) IL-28B genetic variation and treatment response in patients with hepatitis $\mathrm{C}$ virus genotype 3 infection. Hepatology 53: 746-754.

21. Asselah T, De Muynck S, Broët P, Masliah-Planchon J, Blanluet M, et al. (2012) IL-28B polymorphism is associated with treatment response in patients with genotype 4 chronic hepatitis C. J Hepatol 56: 527-532. 
Citation: Kanayama K, Ishii K, Shinohara M, Kogame M, Sumino Y (2012) Type 1 IFN-alpha Receptor Expression in Peripheral Blood Lymphocytes Independently Predicts Sustained Virological Response in Chronic Hepatitis C Genotype 1b with High Viral Load. J Blood Lymph 2:109. doi:10.4172/2165-7831.1000109

22. Honda M, Sakai A, Yamashita T, Nakamoto Y, Mizukoshi E, et al. (2010) Hepatic ISG expression is associated with genetic variation in IL28B and the outcome of IFN therapy for chronic hepatitis C. Gastroenterology 139: 499-509.

23. Taniguchi H, Iwasaki $Y$, Takahashi A, Shimomura H, Moriya A, et al. (2007) Intrahepatic mRNA levels of type 1 interferon receptor and interferon stimulated genes in genotype $1 \mathrm{~b}$ chronic hepatitis $\mathrm{C}$. Association between IFNAR1 mRNA level and sustained response to interferon therapy. Intervirology 50: 32-39.

24. Fujiwara D, Hino K, Yamaguchi Y, Kubo Y, Yamashita S, et al. (2004) Type 1 interferon receptor and response to interferon therapy in chronic hepatitis $C$ patients: a prospective study. J Viral Hepat 11: 136-140.
25. Yamaguchi Y, Hino K, Fujiwara D, Ren F, Katoh Y, et al. (2002) Expression of type I interferon receptor in liver and peripheral blood mononuclear cells in chronic hepatitis C patients. Dig Dis Sci 47: 1611-1617.

26. Jones SM, Foreman SK, Shank BB, Kurten RC (2002) EGF receptor downregulation depends on a trafficking motif in the distal tyrosine kinase domain. Am J Physiol Cell Physiol 282: C420-C433.

27. Datta S, Hazari S, Chandra PK, Samara M, Poat B, et al. (2011) Mechanism of $\mathrm{HCV}$ 's resistance to IFN- $\alpha$ in cell culture involves expression of functional IFN- $\alpha$ receptor 1. Virol J 8: 351-357. 